УДК 159.9-057

DOI https://doi.org/10.32838/2709-3093/2021.3/21

\title{
Немеш В.I.
}

Університет сучасних знань,

ТОВ «Укрполіпак»

\section{ПСИХОЛОГІЧНА МОДЕЛЬ ПОДОЛАННЯ ЕМОЦІЙНОГО НЕБЛАГОПОЛУЧЧЯ В ПІДЛІТКОВОМУ ВІЦІ}

\begin{abstract}
У статті розглядається питання побудови психологічної моделі подолання емоиійного неблагополуччя у підлітковому вічі. Визначено основні проблеми емоційного неблагополуччя у підлітковому віці. Проведено емпіричне дослідження негативних емоційних станів підлітків на базі Ірпінського державного коледжу економіки та права. У дослідженні взяло участь 60 підлітків віком від 15 до 17 років. Під час дослідження було використано наступний психодіагностичний інструментарій: методика первинної діагностики та виявлення дітей «групи ризику» за М.I. Рожковою та М.А. Ковальчук, яка дозволяє оцінити стосунки в родині, рівень агресивності, ступінь довіри до оточуючих та самоочінку підлітка; шкала депресії (Т. Балашова) для оцінки ступеня вираженості депресії. Дослідження було проведено у три етапи. На першому етапі було проведено первинну психодіагностику респондентів. 3 а результатали первинної психодіагностики було обрано групу студентів, у яких були завищені показники за обраними методиками, з якими було проведено психокорекиійні заняття. Після психокорекиійного впливу було проведено вторинну психодіагностику для аналізу ефективності запропонованої психологічної моделі подолання емочійного неблагополуччя підлітків. Психокорекційна програма включала 4 заняття. Тривалість кожного заняття 80 хвилин. Заняття проводились 1 раз на тиждень у двох міні-групах по 13 осіб. Загальна структура занять поділялася на 4 частини: вступна; інформачійна; основна; заключна. Аналіз ефективності запропонованої програми психокорекції дозволив нам зробити висновок, щзо ия модель психологічного втручання є ефективною, оскільки спостерігаються тенденції до зменшення показників за обраними методиками психодіагностики. У дослідженні було розглянуто лише декілька аспектів емочійного неблагополуччя підлітків, тому воно може стати базою для подальших досліджень иієї проблематики з включенням інших негативних емоційних станів, які переживають підлітки.
\end{abstract}

Ключові слова: емоційне неблагополуччя, підлітковий вік, психокорекиія, моделі психологічного впливу, агресія, недовіра до людей, самооцінка, сімейні проблеми, депресивні стани.

Постановка проблеми. Підлітковий вік - це перехідний етап від дитинства до юнацтва. Більшість вчених пов'язують початок підліткового віку з початком статевого дозрівання, а завершення асоціюють з моментом, коли індивід досягає незалежності у своїх вчинках, тобто коли хлопець або дівчина дозріває емоційно, соціально та оволодіває мотивацією до виконання ролі дорослого [8]. У підлітковому віці можуть виникнути різноманітні психологічні проблеми, які без належної підтримки та уваги з боку дорослих і професіоналів можуть мати вкрай негативні наслідки у майбутньому. Однією з таких психологічних проблем підлітків $є$ емоційне неблагополуччя, яке характеризується нестабільністю та неадекватністю емоційних реакцій під час взаємодії з оточуючими [4]. Цей стан виражається у переважанні негативних емоцій, вираженій тривожності та наявності страхів, а також заниженій самооцінці. Прояви негативних емоцій та емоційних станів, таких як тривожність, агресивність, створюють основу емоційного неблагополуччя особистості та заважають в повсякденному житті. 3 огляду на важливість «екологічного» перебігу підліткового віку проблема побудови психологічних моделей подолання емоційного неблагополуччя підлітків набуває неабиякої актуальності.

Аналіз останніх досліджень і публікацій. Питання емоційного неблагополуччя підіймається у працях багатьох зарубіжних та вітчизняних вчених. Так, у роботах Л.А. Абрамян, Л.С. Виготського, А.І. Захарова, М.М. Ліблінг та інших зазначається, що емоційне неблагополуччя зазвичай виникає внаслідок негативних емоційних переживань. Більшість дослідників, серед них А.І. Захаров, I.I. Мамайчук, В.В. Юстицький, визнають, що головну роль у виникненні емоційного неблагополуччя грає соціальна ситуація 
розвитку. Праці Д.Н. Ісаєва, I.I. Мамайчук, М. Раттер присвячені дослідженню взаємозв' язку емоційного неблагополуччя дітей та соматичних захворювань, що у них присутні. Дослідники зазначають, що між соматичним здоров'ям та емоційним неблагополуччям існує тісний зв'язок, оскільки присутність порушень здоров'я може заважати соціальній адаптації та створює особливості формування самооцінки індивіда. В дослідженнях зарубіжних авторів, таких як Г.І. Каплан та Б.Д. Седок, було виявлено тісний взаємозв'язок між депресивними станами у дітей та аналогічними станами у їх батьків. Попри те, що існує безліч праць, що досліджують питання емоційного неблагополуччя, залишається малодослідженим питання побудови психологічних моделей подолання емоційного неблагополуччя у підлітковому віці.

Постановка завдання. Метою роботи $\epsilon$ дослідити ефективність запропонованої психологічної моделі подолання емоційного неблагополуччя у підлітковому віці.

Виклад основного матеріалу дослідження. На базі Ірпінського державного коледжу економіки та права було проведено емпіричне дослідження підлітків у віці 15-17 років. Вибірка склала 60 студентів (27 хлопців і 33 дівчини).

Під час дослідження було використано такий психодіагностичний інструментарій: методика первинної діагностики та виявлення дітей «групи ризику» за М.І. Рожковою та М.А. Ковальчук, яка дозволяє оцінити стосунки в родині, рівень агре- сивності, ступінь довіри до оточуючих та самооцінку підлітка; шкала депресії (Т. Балашова) для оцінки ступеня вираженості депресії [7]. Дослідження було проведено у три етапи. На першому етапі було проведено первинну психодіагностику респондентів. За результатами первинної психодіагностики було обрано групу студентів, у яких були завищені показники за обраними методиками, 3 якими було проведено психокорекційні заняття. Після психокорекційного впливу було проведено вторинну психодіагностику для аналізу ефективності запропонованої психологічної моделі подолання емоційного неблагополуччя підлітків. Розглянемо результати первинної психодіагностики. На рис. 1 зображені результати за методикою первинної діагностики та виявлення дітей «групи ризику» за М.I. Рожковою та М.А. Ковальчук. До групи психокорекційного впливу потрапили респонденти з високим рівнем депресії, субдепресивним станом, а також ті, у кого завищений хоча б один показник за методикою М.I. Рожкової та М.А. Ковальчук. Наступним кроком у нашому дослідженні було проведення психокорекційних занять. Програму було складено, спираючись на психолого-педагогічні праці А. Анджейчак [1], I.С. Вітренко [2] та А.Н. Ленського [6]. Психокорекційна програма включала 4 заняття. Тривалість кожного заняття 80 хвилин. Заняття проводились 1 раз на тиждень у двох мінігрупах по 13 чоловік. Загальна структура занять поділялася на 4 частини: вступна (до 15 хв.), метою якої було створення сприятливого психо-

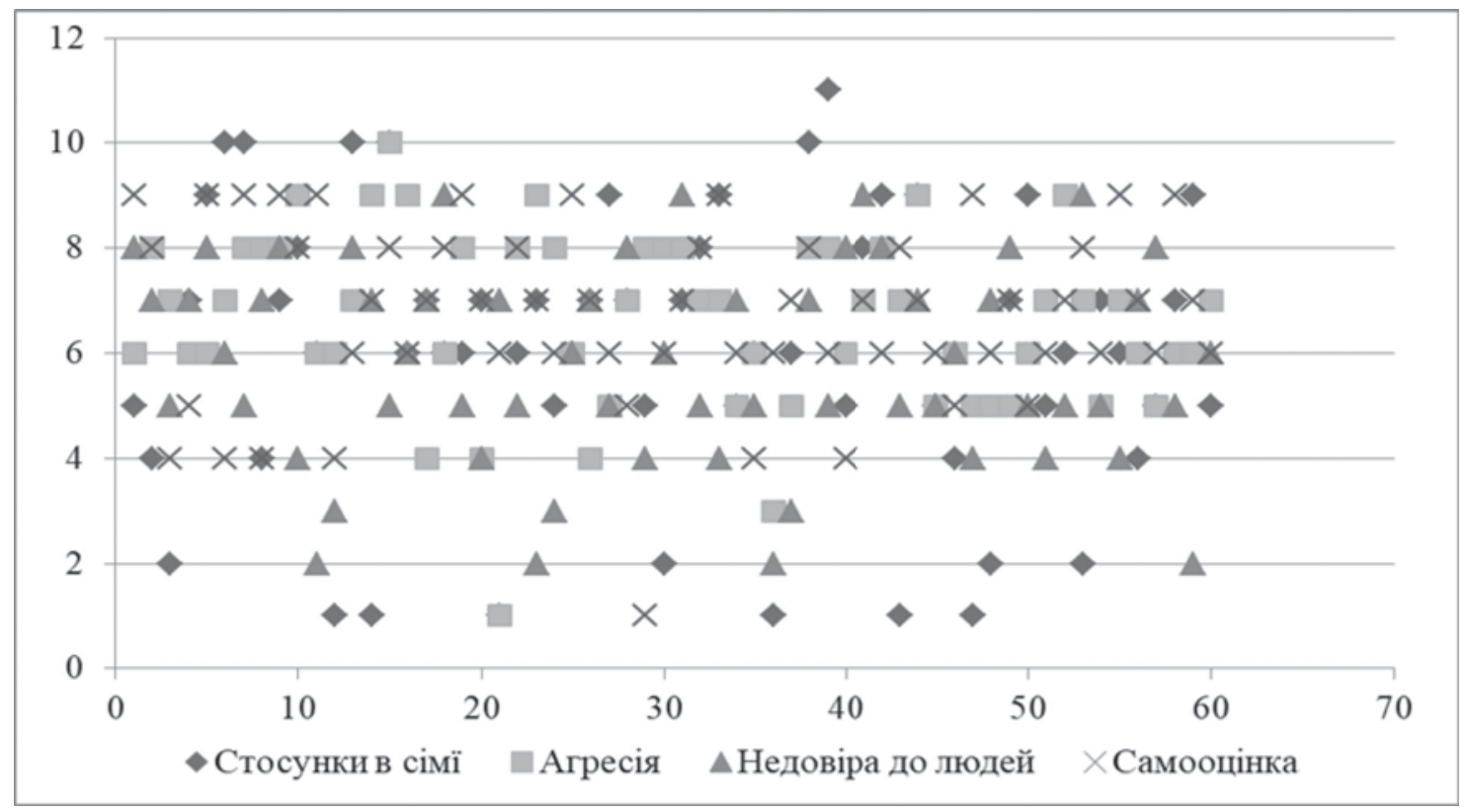

Рис. 1. Результати методики первинної діагностики та виявлення дітей «групи ризику» за М.I. Рожковою та М.А. Ковальчук 
логічного простору, налагодження зворотного зв' язку та засвоєння правил роботи; інформаційна (до 15 хв.), метою якої була оцінка рівня поінформованості підлітків щодо проблеми, яка розглядалася на занятті, та надання інформаціі; основна (до 40 хв.), метою якої було проведення вправ та засвоєння нових знань, формування умінь та навичок; завершальна (до 20 хв.), метою якої було підбиття підсумків, оцінка отриманого досвіду, зворотній зв'язок, рефлексія та проведення психогімнастичних вправ.

Як ми можемо побачити 3 рис. 1, за методикою M.I. Рожкової та М.А. Ковальчук за шкалою стосунків в сім’ї у 16 респондентів (26,6\%) прослідковується негативне сприйняття сімейного психологічного клімату. За шкалою агресії у 46 респондентів (76,6\%) спостерігаються завищені показники, причому 3 цих 46 респондентів, у яких проявлена агресія, 14 мають граничний показник, i 32 - завищений. За шкалою недовіри до людей у 25 респондентів $(41,6 \%)$ спостерігається підвищена недовіра та складність у побудові соціальних контактів. I за шкалою самооцінки у 33 респондентів (55\%) виявлено занижену самооцінку.

Розглянемо результати діагностики за шкалою депресії (Т. Балашова) (рис. 2).

Як ми можемо побачити з рисунку 2, за результатами діагностики за методикою Т. Балашова у 4 респондентів (6,7\%) було виявлено високий рівень депресіі. У 22 респондентів (36,7\%) було виявлено субдепресивний стан, у 8 (13,3\%) легку ситуативну чи стресову депресію, i у 26 респондентів (43,3\%) депресія відсутня.

За результатами первинної психодіагностики було визначено групу психокорекційного впливу, до якої увійшли 26 студентів (табл. 1).

Детальну структуру занять наведено у табл. 2 .

Метою першого заняття було зміцнення емоційного контакту з підлітками, зниження емоційного напруження та рівня ситуативної агресії. Під час проведення першого заняття було використано аркуші паперу A4, «Дві скриньки», подушки для биття різного розміру, кольорові олівці, липку стрічку, ножиці.

Метою другого заняття було зміцнення емоційного контакту з підлітками, сприяння усвідомленню підлітками власних емоцій та поведінки, причин та наслідків. Під час цього заняття було використано «Дві скриньки», аркуші паперу А4, кольорові олівці, фломастери, склянку, кілька пляшок з водою різного кольору, воду.

Метою третього заняття було навчити підлітків прийомам емоційного реагування. Під час цього заняття було використано «Дві скриньки», велику миску для «салату», аркуші різнокольорового паперу, ножиці, окуляри, іграшки, аркуші паперу A4, банку з кришкою.

Метою четвертого заняття було сформувати вміння та навички конструктивного спілкування та поведінки в конфліктних ситуаціях; розви-

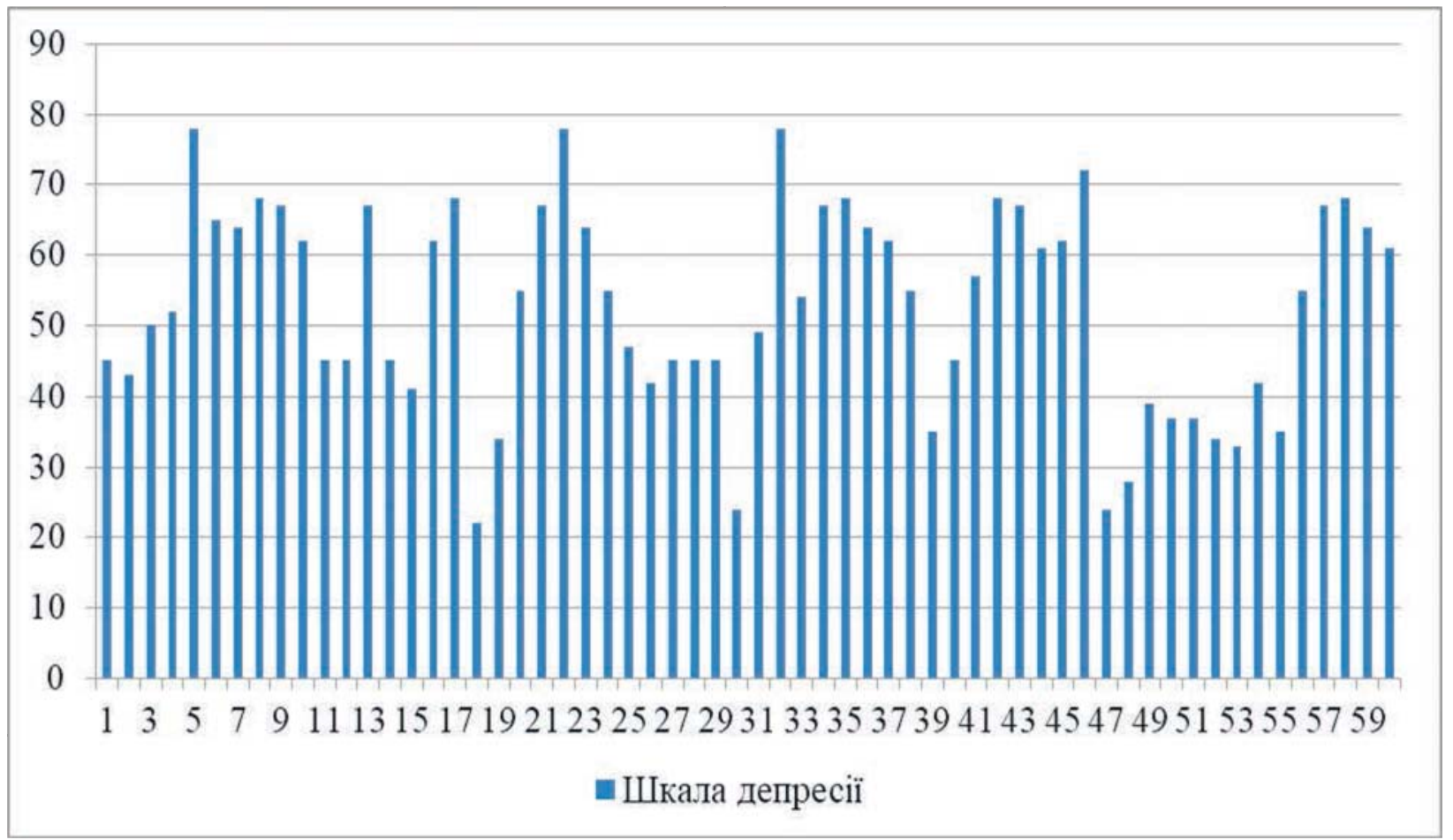

Рис. 2. Результати діагностики за шкалою депресії (Т. Балашова) 
Таблиця 1

Показники первинної психодіагностики респондентів, що увійшли до групи психокорекційного впливу

\begin{tabular}{|c|c|c|c|c|c|}
\hline \multirow{2}{*}{$\begin{array}{c}\text { № } \\
\text { п/п }\end{array}$} & \multicolumn{3}{|c|}{ Методика М.І. Рожкової та М.А. Ковальчук } & Шкала депре- \\
\cline { 2 - 5 } сії
\end{tabular}

Таблиця 2

Структура програми психокорекції, спрямованої на подолання емоційного неблагополуччя

\begin{tabular}{|c|c|c|c|}
\hline Назва & Напрям роботи & Вправи & № заняття \\
\hline \multirow{4}{*}{ Корекційний етап } & $\begin{array}{c}\text { Зниження емоційного напру- } \\
\text { ження та рівня ситуативної } \\
\text { агресії }\end{array}$ & $\begin{array}{c}\text { 1. «Мій образ» } \\
\text { 2. «Дві скриньки» } \\
\text { 3. «Вибивання пилу» } \\
\text { 4. «Апельсин» } \\
\text { 5. «Здуй чоловічка на місце» }\end{array}$ & 1 \\
\hline & $\begin{array}{c}\text { Усвідомлення власних емо- } \\
\text { цій та поведінки, причин та } \\
\text { наслідків }\end{array}$ & $\begin{array}{c}\text { 1. «Бінго» } \\
\text { 2. «Дві скриньки» } \\
\text { 3. «Як виглядає мій гнів» } \\
\text { 4. «Склянка води» } \\
\text { 5. «Стани моря» }\end{array}$ & 2 \\
\hline & $\begin{array}{c}\text { Засвоєння прийомів емоцій- } \\
\text { ного реагування }\end{array}$ & $\begin{array}{l}\text { 1. «Кулінари» } \\
\text { 2. «Дві скриньки» } \\
\text { 3. «Окуляри агресії» } \\
\text { 4. «Гнівний лист» } \\
\text { 5. «Банка крику» }\end{array}$ & 3 \\
\hline & $\begin{array}{c}\text { Формування умінь та нави- } \\
\text { чок конструктивного спілку- } \\
\text { вання та поведінки в кон- } \\
\text { фліктних ситуаціях }\end{array}$ & $\begin{array}{c}\text { 1. Мімічна гімнастика } \\
\text { 2. «Відгадай, що я відчув» } \\
\text { 3. «Відгадай, що він відчув» } \\
\text { 4. «Віддай мені» } \\
\text { 5. «Я - до, я - після» }\end{array}$ & 4 \\
\hline
\end{tabular}


ток емпатії та співчуття. Матеріалами для цього заняття стали ситуативні картинки, «окуляри агресії», короткометражний дитячий мультфільм 3 повчальним змістом.

Після проведення психокорекційних занять було здійснено повторну психодіагностику для аналізу ефективності запропонованого методу психологічного впливу (табл. 3).

Як ми можемо побачити з таблиці, показники за обома методиками зменшилися. Так, середне значення показника стосунків у сім'ї до психокорекційного впливу складало 6,3, а після - 5,07 (середній показник зменшився на 1,26). Середнє значення показника рівня агресії до проведення психокорекційних занять складало 6,5, а після - 5,03 (середній показник зменшився на $1,46)$. Середнє значення показника рівня недовіри до людей до психокорекційного втручання становило 5,65, а після - 4,3 (середній показник зменшився на 1,34). Середнє значення показника самооцінки до психокорекційного впливу становило 6,6, а після - 4,1 (середній показник зменшився на 2,5). Середній показник за шкалою депресії до психокорекційного втручання складав 66,8 , а після - 62 (середній показник зменшився на 4,8).

Таким чином, можемо сказати, що запропонована модель психологічного супроводу емоційного неблагополуччя підлітків є ефективною. Особливо ця ефективність проявляється у показниках самооцінки та агресії. Слід зазначити, що більшість показників все ще залишилися завищеними або граничними, проте спостерігається позитивна тенденція до зменшення проявів негативних емоційних станів підлітків.

Таблиця 3

Показники вторинної психодіагностики респондентів після проведення психокорекційних занять

\begin{tabular}{|c|c|c|c|c|c|c|c|c|c|c|}
\hline \multirow[b]{2}{*}{ № ா/ா } & \multicolumn{8}{|c|}{ Методика М.І. Рожкової та М.А. Ковальчук } & \multirow[b]{2}{*}{$\begin{array}{l}\text { Шкала } \\
\text { депре- } \\
\text { сії (до) }\end{array}$} & \multirow[b]{2}{*}{$\begin{array}{c}\text { Шкала } \\
\text { депре- } \\
\text { сії } \\
\text { (після) }\end{array}$} \\
\hline & $\begin{array}{c}\text { Сто- } \\
\text { сунки в } \\
\text { сім’ї (до) }\end{array}$ & $\begin{array}{c}\text { Сто- } \\
\text { сунки } \\
\text { в сім’ї } \\
\text { (після) } \\
\end{array}$ & $\begin{array}{c}\text { Агре- } \\
\text { сія } \\
\text { (до) }\end{array}$ & $\begin{array}{c}\text { Агре- } \\
\text { сія } \\
\text { (після) }\end{array}$ & $\begin{array}{c}\text { Недо- } \\
\text { віра до } \\
\text { людей } \\
\text { (до) }\end{array}$ & $\begin{array}{c}\text { Недо- } \\
\text { віра до } \\
\text { людей } \\
\text { (після) }\end{array}$ & $\begin{array}{c}\text { Само- } \\
\text { оцінка } \\
\text { (до) }\end{array}$ & $\begin{array}{l}\text { Само- } \\
\text { оцінка } \\
\text { (після) }\end{array}$ & & \\
\hline 1 & 9 & 8 & 6 & 5 & 8 & 7 & 9 & 7 & 78 & 72 \\
\hline 2 & 6 & 5 & 8 & 6 & 5 & 5 & 8 & 4 & 78 & 71 \\
\hline 3 & 8 & 8 & 7 & 7 & 5 & 5 & 8 & 4 & 78 & 72 \\
\hline 4 & 4 & 5 & 6 & 5 & 6 & 7 & 5 & 4 & 72 & 60 \\
\hline 5 & 4 & 3 & 8 & 6 & 7 & 7 & 4 & 5 & 68 & 65 \\
\hline 6 & 7 & 5 & 4 & 3 & 7 & 5 & 7 & 7 & 68 & 61 \\
\hline 7 & 6 & 5 & 6 & 4 & 5 & 5 & 4 & 3 & 68 & 64 \\
\hline 8 & 9 & 7 & 8 & 6 & 8 & 6 & 6 & 4 & 68 & 61 \\
\hline 9 & 7 & 5 & 6 & 4 & 5 & 4 & 9 & 4 & 68 & 61 \\
\hline 10 & 7 & 5 & 8 & 6 & 8 & 5 & 9 & 5 & 67 & 62 \\
\hline 11 & 10 & 8 & 7 & 5 & 8 & 5 & 6 & 7 & 67 & 61 \\
\hline 12 & 1 & 1 & 1 & 1 & 7 & 7 & 6 & 4 & 67 & 62 \\
\hline 13 & 5 & 5 & 5 & 5 & 7 & 4 & 6 & 4 & 67 & 57 \\
\hline 14 & 1 & 1 & 7 & 5 & 5 & 4 & 8 & 5 & 67 & 61 \\
\hline 15 & 5 & 5 & 5 & 5 & 8 & 4 & 6 & 2 & 67 & 62 \\
\hline 16 & 10 & 7 & 7 & 6 & 6 & 5 & 4 & 2 & 65 & 47 \\
\hline 17 & 10 & 7 & 8 & 7 & 5 & 4 & 9 & 1 & 64 & 61 \\
\hline 18 & 7 & 4 & 9 & 5 & 2 & 1 & 7 & 4 & 64 & 62 \\
\hline 19 & 1 & 1 & 3 & 3 & 2 & 1 & 6 & 3 & 64 & 63 \\
\hline 20 & 9 & 7 & 6 & 4 & 2 & 2 & 7 & 4 & 64 & 62 \\
\hline 21 & 8 & 4 & 9 & 7 & 4 & 4 & 8 & 5 & 62 & 62 \\
\hline 22 & 6 & 4 & 9 & 7 & 6 & 5 & 6 & 4 & 62 & 61 \\
\hline 23 & 6 & 5 & 5 & 5 & 3 & 0 & 7 & 5 & 62 & 61 \\
\hline 24 & 5 & 5 & 5 & 5 & 5 & 2 & 6 & 4 & 62 & 60 \\
\hline 25 & 9 & 7 & 9 & 4 & 7 & 4 & 7 & 4 & 61 & 60 \\
\hline 26 & 5 & 5 & 7 & 5 & 6 & 4 & 6 & 4 & 61 & 61 \\
\hline $\begin{array}{c}\text { Середнє } \\
\text { зна- } \\
\text { чення }\end{array}$ & 6,3 & 5,07 & 6,5 & 5,03 & 5,65 & 4,3 & 6,6 & 4,1 & 66,8 & 62 \\
\hline
\end{tabular}


Висновки 3 проведеного дослідження. Проведене дослідження дозволило нам дослідити питання емоційного неблагополуччя підлітків та психологічної моделі його подолання.

Було виявлено, що серед респондентів 6,7\% мають високий рівень депресії, а $36,7 \%$ респондентів мають проявлений субдепресивний стан. Також було виявлено, що у 26,6\% респондентів завищені показники за шкалою сімейних стосунків, що вказує на проблеми у родині, у 76,6\% підлітків завищений рівень агресивності, у 41,6\% підлітків завищений рівень недовіри до людей, та у 55\% респондентів занижена самооцінка.

Аналіз ефективності запропонованої програми психокорекції дозволив нам зробити висновок, що ця модель психологічного втручання є ефективною, оскільки спостерігаються тенденції до зменшення показників за обраними методиками психодіагностики. У дослідженні було розглянуто лише декілька аспектів емоційного неблагополуччя підлітків, тому воно може стати базою для подальших досліджень цієї проблематики з включенням інших негативних емоційних станів, які переживають підлітки.

\section{Список літератури:}

1. Анджейчак А. Психолого-педагогічні умови формування творчої особистості дитини в освітньовиховних закладах. Обдарована дитина. 2000. № 5. С. 8-13

2. Вітенко І.С., Борисюк А.С., Вітенко T.І. Основи психології. Основи педагогіки : навч.-метод. посібник. 2-ге вид. Чернівці : Книги-XXI, 2009. 200 с.

3. Дуткевич Т.В. Загальна психологія. Теоретичний курс : навч. посіб. для студентів; Кам'янець-Поділ. нац. ун-т ім. Івана Огієнка, Факультет корекц. та соц. педагогіки і психології, каф. психології освіти. Кам’янець-Подільський: Зволейко Д. Г. [вид.], 2015. 431 с.

4. Ильин Е.П. Эмоции и чувства. Мастера психологии Санкт-Петербург : Изд. «Питер», 2001. 752 c.

5. Кокун О.М. К 59 Психофізіологія. Навчальний посібник. Київ : Центр навчальної літератури, 2006. $184 \mathrm{c}$.

6. Леонтьев А.Н. Потребности, мотивы и эмоции : Конспект лекций / Кафедра общ. психологии. Москва : Изд-во Моск. ун-та, 1971.38 с.

7. Психологу для роботи. Діагностичні методики: збірник; уклад.: М.В. Лемак, В.Ю. Петрище. Вид. 2-ге. Виправл. Ужгород : Видавництво Олександри Гаркуші, 2012. 616 с.

8. Сергєєнкова О.П., Столярчук О.А., Коханова О.П., Пасєка О.В. Загальна психологія. навч. посіб. Київ : Центр учбової літератури, 2012. 296 с.

\section{Nemesh V.I. PSYCHOLOGICAL MODEL OF OVERCOMING EMOTIONAL DISTRESS IN ADOLESCENCE}

The article considers the issue of building a psychological model of overcoming emotional distress in adolescence. The main problems of emotional distress in adolescence have been identified. An empirical study of negative emotional states of adolescents was carried on the basis of Irpin State College of Economics and Law. The study involved 60 adolescents aged from 15 to 17 years. During the study, the following psychodiagnostic tools were used: the method of primary diagnosis and identification of children "at risk" by M.I. Rozhkova and M.A. Kovalchuk, which allowed us to assess family relationships, the level of aggression, the degree of trust in others and the self-esteem of the adolescent; depression scale (T. Balashov) to assess the severity of depression. The study was conducted in three stages. At the first stage, the primary psychodiagnostics of the respondents was performed. According to the results of the primary psychodiagnostics, a group of students was selected who had overestimated indicators according to the selected methods, with which psycho-correctional classes were conducted. After psycho-correctional exposure, secondary psychodiagnostics was performed to analyze the effectiveness of the proposed psychological model of overcoming the emotional distress of adolescents. The psycho-correctional program included 4 classes. The duration of each lesson is 80 minutes. Classes were held once a week, in two mini-groups of 13 people. The general structure of classes was divided into 4 parts: introductory; informational; basic; concluding. Analysis of the effectiveness of the proposed program of psycho-correction, allowed us to conclude that this model of psychological intervention is effective, as there are tendencies to reduce the indicators of the selected methods of psychodiagnostics. The study considered only a few aspects of adolescent emotional distress, so it can be the basis for further research on this issue, including other negative emotional states experienced by adolescents.

Key words: emotional distress, adolescence, psycho-correction, models of psychological influence, aggression, distrust of people, self-esteem, family problems, depression. 